\title{
Neutron Activation Analysis of Atmospheric Aerosols from a Small Pacific Island Country: A Case of Suva, Fiji Islands
}

\author{
Sitaram Garimella*, Ravin N. Deo \\ Physics Division, School of Engineering and Physics, Faculty of Science and Technology, \\ The University of the South Pacific, Private Mail Bag, Suva, Fiji Islands.
}

\begin{abstract}
A systematic study was developed to investigate the quality of air in Suva, the capital city of Fiji Islands. This is the first work of its kind in the South Pacific Islands and was aimed at characterizing the elemental abundances in total suspended particulate (TSP) matter in Suva's air. Aerosol samples were collected from 11 locations in Suva during the period 2000-2003 using a high-volume sampler. Concentrations of some heavy metals and other trace elements in these atmospheric aerosols were investigated by neutron activation analysis and gamma spectrometry. Concentrations of total suspended particulates for residential, traffic and industrial areas were found to be in the range 9-43, 20-58 and 33-91 $\mu \mathrm{g} / \mathrm{m}^{3}$, respectively. The elements sodium, iron and zinc have been observed in relatively higher concentrations than other elements. Moreover, calculated enrichment factors for some elements (such as arsenic, bromine, cobalt, chromium and antimony) reveal possible anthropogenic inputs into air mainly through automobile exhaust emissions.
\end{abstract}

Keywords: Suva; Air; Suspended particulates; HPGe spectrometer.

\footnotetext{
*Corresponding author. Tel.: +679 323 2419, Fax: +679 3231511

E-mail address: sitaram.garimella@usp.ac.fj
} 


\section{INTRODUCTION}

Airborne particulate matter - also known as aerosols - consists of solid and/or liquid particles of sizes in the range 0.01-100 $\mu \mathrm{m}$ suspended in air, which occur through natural processes such as volcanic eruptions, windblown dust, sea spray, etc., or through anthropogenic sources like industrial emissions, automobile exhausts, etc. Natural sources, like dust, generally contribute aerosols of sizes $>10 \mu \mathrm{m}$ in diameter, while anthropogenic sources contribute $<10 \mu \mathrm{m}$ (classified under $\mathrm{PM}_{10}$ ) sized aerosols (Rao and Rao, 1989). It is generally accepted that the concentration of total suspended particulates (TSP) from natural origins is less than $10 \mu \mathrm{g} / \mathrm{m}^{3}$ (Le Petit et al., 2002). For example, the TSP concentration of the Antarctic atmosphere is in the range of 170-300 $\mathrm{ng} / \mathrm{m}^{3}$ (Shaw, 1980). High levels of TSP in air can reduce atmospheric visibility, irritate the eyes and can have long-term effects on human, plant and animal life (Bridgeman, 1990). The toxic properties of particles are partly due to biochemical activities of metals present in them. In recent times, particulate matter pollution in urban air has become common and a serious problem in many developing countries (e.g., Aneja et al., 2001; Bilos et al., 2001; Salaam et al., 2003). The World Health Organisation (WHO) advises that concentration of TSP in air should not exceed the annual average of $60-90 \mu \mathrm{g} / \mathrm{m}^{3}$, while the air quality guideline in most developed countries is 90 $\mu \mathrm{g} / \mathrm{m}^{3}$ annually and $120-150 \mu \mathrm{g} / \mathrm{m}^{3}$ daily (Boubel et al., 1994). Since $\mathrm{PM}_{10}$ aerosols are inhalable, a daily maximum of $50 \mu \mathrm{g} / \mathrm{m}^{3}$ is the accepted guideline in many countries (e.g., Hope and Gooding, 2001).

The Pacific region and the individual island nations have made a strong commitment to efforts to prevent irreversible environmental change and to promote sustainable development by becoming party to numerous environmental conventions and treaties, such as the Framework Convention on Climate Change (FCCC, 1992), the Convention on Biological Diversity (CBD, 1992), the Convention to Combat Desertification (CCD, 1994), the Convention on International Trade in Endangered Fauna and Flora (CITES, 1973), the Ramsar Convention (1971), the Montreal Protocol (1987) and Kyoto Protocol (1997), to mention only a few. They have, with the assistance of institutions such as South Pacific Regional Environment Program (SPREP), United Nations Development Program (UNDP), Australian Government's Overseas Aid Program (AusAID) and University of the South Pacific (USP), also made a strong commitment, particularly over the past decade, to address the issues of environmental protection and sustainable development at the local and community levels. Participatory approaches to conservation and development have been increasingly used with successful results. Until now, very little information is available on airborne particulate matter in urban air in the South Pacific island countries. Many of these islands are small (20-200 km in diameter), widely scattered in the ocean and are thinly populated. For example in Fiji, fairly rapid population growth, 
modernization and urban drift, rising expectations, and growing inequalities, are contributing to a wide range of growing environmental problems, including air pollution problems.

The current decade has seen considerable efforts on the part of Fiji to enact bills and acts designed to protect the environment and achieve sustainable development. Fiji's Sustainable Development Bill was a case in point. Debated very widely during the second half of the 90's, it was an ambitious and comprehensive environmental bill. Its special air pollution section identified vehicle emission as a major source of air pollution, particularly from leaded petrol. Since then leaded petrol has been phased out (in late 90's) and the Land Transport Authority (LTA) has been imposing stricter control of vehicle emissions. Efforts are being made to enforce existing emission regulation, as well as incorporate regulatory standards, including the certificate of compliance for imports, be they new or used vehicles. There is also some consideration given to a national analytical laboratory for monitoring and implementing air pollution regulations. In addition to auto emissions, there are emissions from a few companies that use waste oil or coal as fuel. The requirement that all incineration facilities get permission from the National Fire Authority partially ensures that excessive emissions do not occur. Moreover, the town and country planning departments exercise control in approving certain industrial activities which are likely to cause air pollution.

In view of the background described earlier, the present work is aimed at a baseline study of air quality in Suva, the capital city of the Fiji Islands. For this purpose, we determined the concentrations of TSP and its elemental composition in various locations of the city.

\section{MATERIALS AND METHODS}

\section{Study area and sampling}

Suva, situated at $178.30^{\circ} \mathrm{E}$ and $18.06^{\circ} \mathrm{S}$, is the largest city of the Fiji Islands (Fig. 1) with an area of $26 \mathrm{~km}^{2}$. The Greater Suva area, which includes Suva and the suburban towns of Lami and Nasinu, has a total population of about 187,000 . About 60,000 persons commute daily into the Suva City. The annual mean temperature at Suva is $27^{\circ} \mathrm{C}$. Suva experiences a wet season between the months of November to April. Suva's mean annual rainfall (about $2800 \mathrm{~mm}$ ) is greatly influenced by the island topography (hilly) and the southeast (SE) trade winds. The SE winds dominate during all seasons, average 15-20 knots, and are most persistent during the period of June to November leading to good atmospheric circulation.

The present study area is restricted to the Suva City and the nearby Lami town. For the purpose of sampling aerosols, the region could be classified into three broad categories; namely, residential, traffic and industrial areas. The sampling sites are shown in Fig. 1. The region's industries (cement, steel, and food processing factories, automobile works, Suva Harbour) mainly lie in Lami and Walu Bay (which is in the vicinity of Lami). The Suva municipal rubbish dump is 
also located in Lami. It is believed that air movement is restricted in these two regions (Lami and Walu Bay) by surrounding mountains. Sampling was carried out in a few residential areas, such as Boron Road, Rifle Range, Tamavuva and the University Campus. Due to numerous creeks in Suva, automobile traffic is confined to the few major roads which connect Suva City to the suburban areas. Some of the locations, which are categorized as traffic, are busy junctions connecting residential areas. Five locations (Samabula, Suva Market, Baily Clinic, Centre Point and Raiwaqa) are chosen as traffic areas. Thus, sampling was carried out at 11 locations in the region from 2000 to 2003 .

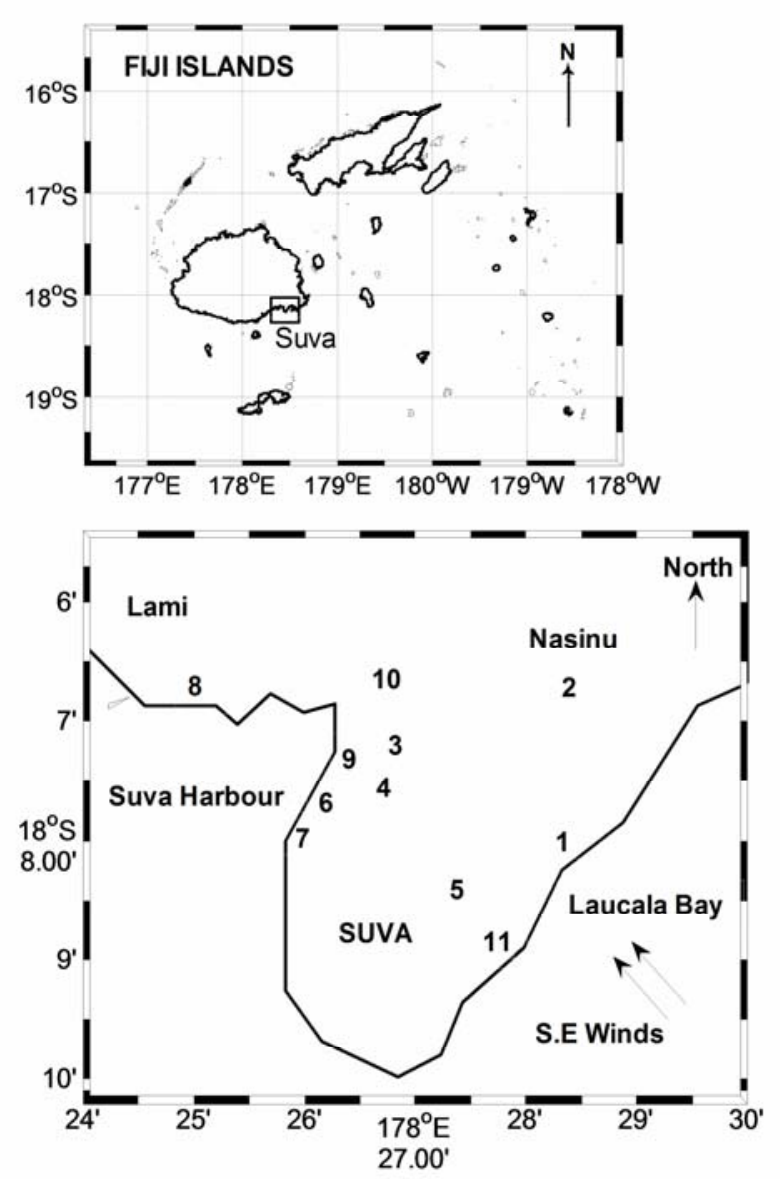

Fig. 1. Map of Suva showing the sampling sites: Rifle Range (1), Centerpoint (2), Samabula (3), Boron Road (4), Raiwaqa (5), Baily Clinic (6), Suva Market (7), Lami (8), Walubay (9), Tamavua (10), and University Campus (11).

Two high-volume air samplers, with flow rates of 1.0 and $2.0 \mathrm{~m}^{3} / \mathrm{min}$, were used to collect aerosols on Whatman-41 filter papers (size $203 \times 254 \mathrm{~mm}^{2}$ ). These filters have a high collection efficiency of over 95\% each for marine aerosols (Prospero et al., 2003) and for aerosols containing ${ }^{7} \mathrm{Be}$ (Uematsu et al., 1994). Further, Whatman-41 filters have very low blank levels of heavy metals and trace elements (USEPA, 1999). For security reasons, the samplers were 
installed at police stations in various parts of Suva. The samplers were run continuously for a week before collecting the filter and about 2-7 (mostly 4) filters were collected from each site. About $6000-8000 \mathrm{~m}^{3}$ of air was drawn through each filter. The meteorological conditions (rainfall, ambient temperature and pressure) were also noted during sampling periods. The weight of each filter was taken in the laboratory before and after exposure under conditions of constant temperature and humidity, and the TSP masses were determined.

\section{Neutron activation analysis}

Elemental abundances in the filters were determined by the neutron activation analysis (NAA) technique (Landsberger, 1994). Since Fiji does not have a nuclear reactor, the filters were irradiated in the HIFAR reactor of the Australian Nuclear Science and Technology Organisation (ANSTO), Sydney. For this purpose, a $(8 \times 1) \mathrm{cm}^{2}$ strip of each filter was folded into a $(1 \times 1)$ $\mathrm{cm}^{2}$ pellet and heat-sealed in a clean polyethylene bag, which was in turn sealed in another polyethylene bag as a precaution to contain radioactivity that would be induced after irradiation. Several United States Geological Survey (USGS) and International Atomic Energy Agency (IAEA) standard samples, of similar size and mass about $50 \mathrm{mg}$, were prepared and stacked together with exposed filter sections (each stack contained 15-20 filters and 5 standards) and irradiated in the reactor at a thermal neutron flux of $2.75 \times 10^{12} 1 /\left(\mathrm{cm}^{2} \mathrm{~s}\right)$ for 4 hours. Thus, a total of 48 exposed filters from various locations (giving an average of about 4 filters per site) were analyzed in this work by NAA. The standards were intended to serve three purposes: a) to make corrections for the non-uniformity of neutron flux received by the samples during irradiation in the reactor, b) to measure the elemental concentrations in filters by using the comparator method, and c) to cross-check the accuracy and reliability of results by treating some of the standards as unknowns.

After a waiting time of 3 days, the irradiated samples were flown back to Suva for measurement of induced activities using an HPGe gamma-ray spectrometer (efficiency $24 \%$ relative to $\mathrm{NaI}$ detector). In the first batch of measurements, which took place immediately after the arrival of the samples in Suva, each sample was measured for 4000 s. Fig. 2 shows a typical gamma-ray spectrum obtained from an activated sample (filter from Centre Point, which is a busy traffic junction), from which the activities of short-lived nuclides $\left(T_{1 / 2} \leq 7 \mathrm{~d}\right)$ were obtained. From these, the concentrations of elements arsenic (As), bromine (Br), lanthanum (La), sodium (Na), antimony $(\mathrm{Sb})$ and samarium $(\mathrm{Sm})$ in each filter were determined. A second batch of measurements, for $6000 \mathrm{~s}$ on each sample, was carried out 3-4 weeks after irradiation and a spectrum similar to Fig. 2 was obtained. By this time, most of the short-lived nuclides were nearly extinct, which enabled the long-lived nuclides to be determined with greater accuracy. From this data, elemental concentrations of cerium $(\mathrm{Ce})$, cobalt $(\mathrm{Co})$, chromium $(\mathrm{Cr})$, europium 
$(\mathrm{Eu})$, iron $(\mathrm{Fe})$, hafnium (Hf), scandium $(\mathrm{Sc})$, strontium $(\mathrm{Sr})$, tantalum $(\mathrm{Ta})$, thorium $(\mathrm{Th})$, ytterbium $(\mathrm{Yb})$ and zinc $(\mathrm{Zn})$ were calculated.

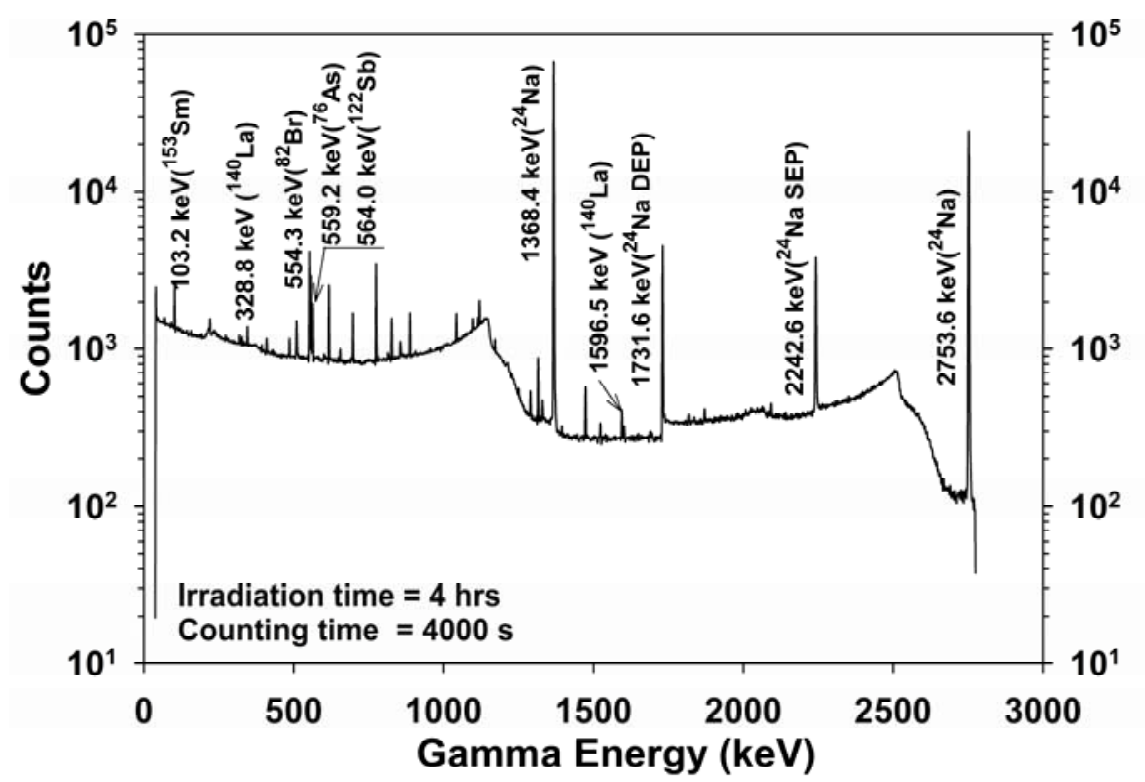

Fig. 2. Gamma-ray spectrum obtained from an activated filter from Centre Point (a busy traffic junction) 5 days after irradiation. This spectrum enabled determination of concentrations of elements As, $\mathrm{Br}, \mathrm{La}, \mathrm{Na}, \mathrm{Sb}$ and $\mathrm{Sm}$ in the filter.

\section{RESULTS AND DISCUSSION}

\section{The TSP distribution}

Visual inspection of filters collected from traffic areas revealed that they were loaded heavily with fine carbon soot, while filters from industrial areas showed somewhat coarser particles.

Tables 1(a)-(c) give the summary of meteorological conditions during the sampling period and also show the measured concentrations of TSP in air at various locations. Although a wide variability in TSP was observed at different locations, TSP levels within the categorized locations (industrial, traffic or residential areas) were similar.

TSP levels were found to be $33-91 \mu \mathrm{g} / \mathrm{m}^{3}$ for industrial areas, $20-50 \mu \mathrm{g} / \mathrm{m}^{3}$ for traffic areas, and $9-43 \mu \mathrm{g} / \mathrm{m}^{3}$ for residential areas. To comment on the quality of air in Suva, these TSP values must be compared with the WHO Annual Guideline of $60-90 \mu \mathrm{g} / \mathrm{m}^{3}$. The climatology of Suva (strong southeast trade winds and heavy rainfall) is responsible for such low TSP values than in most urbanized cities in the developing world (e.g., $400 \mu \mathrm{g} / \mathrm{m}^{3}$ in New Delhi; see Aneja et al., 2001). The highest variability in TSP levels was observed in industrial areas of Suva. As can be seen from Table 1, these levels are close to the WHO Guidelines. TSP levels observed at traffic zones are below the lower WHO Guideline of $60 \mu \mathrm{g} / \mathrm{m}^{3}$. But residents of Suva complain often about high pollution levels at the traffic areas of the Centre Point and the Suva Market (adjacent to 


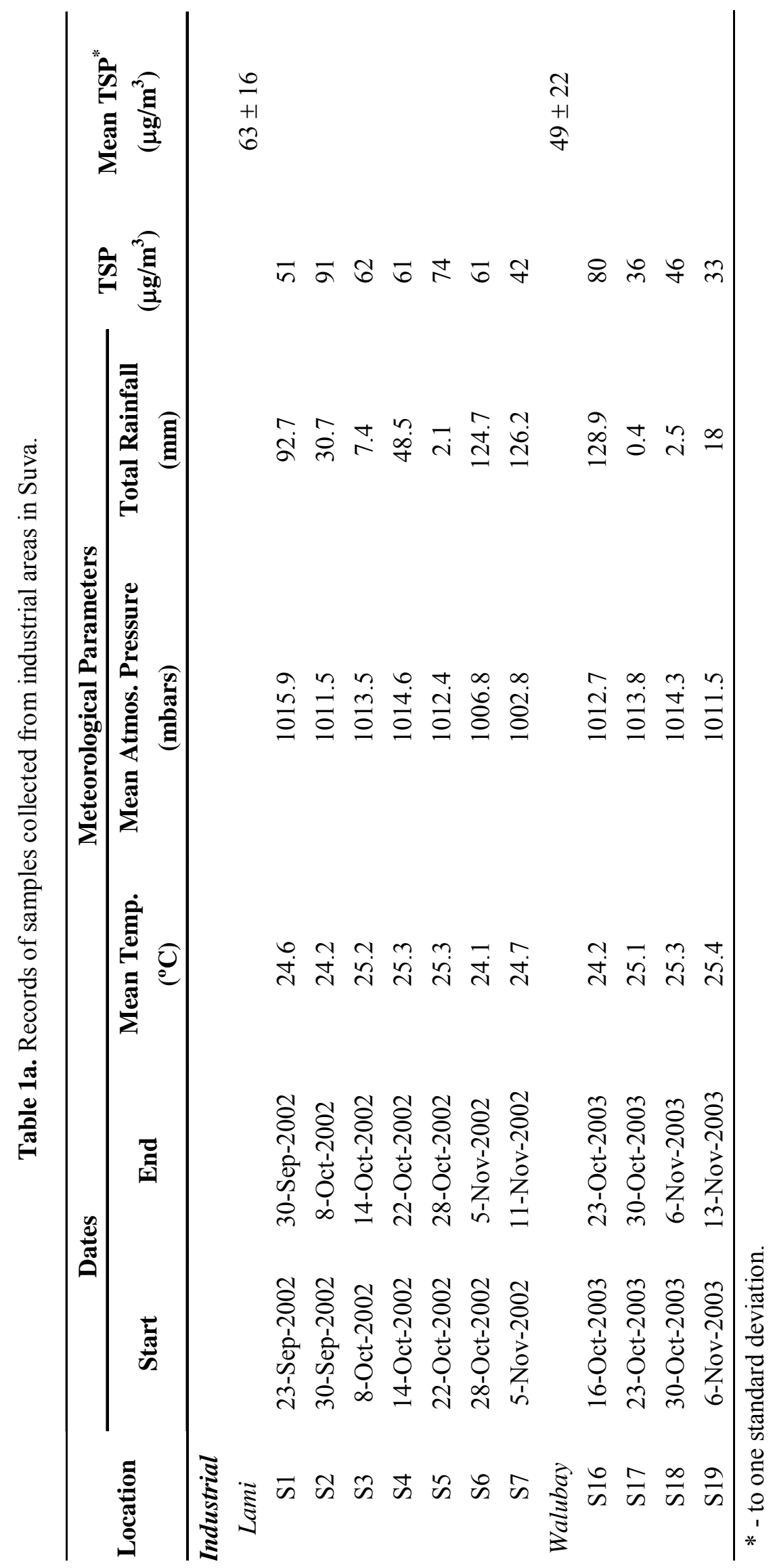




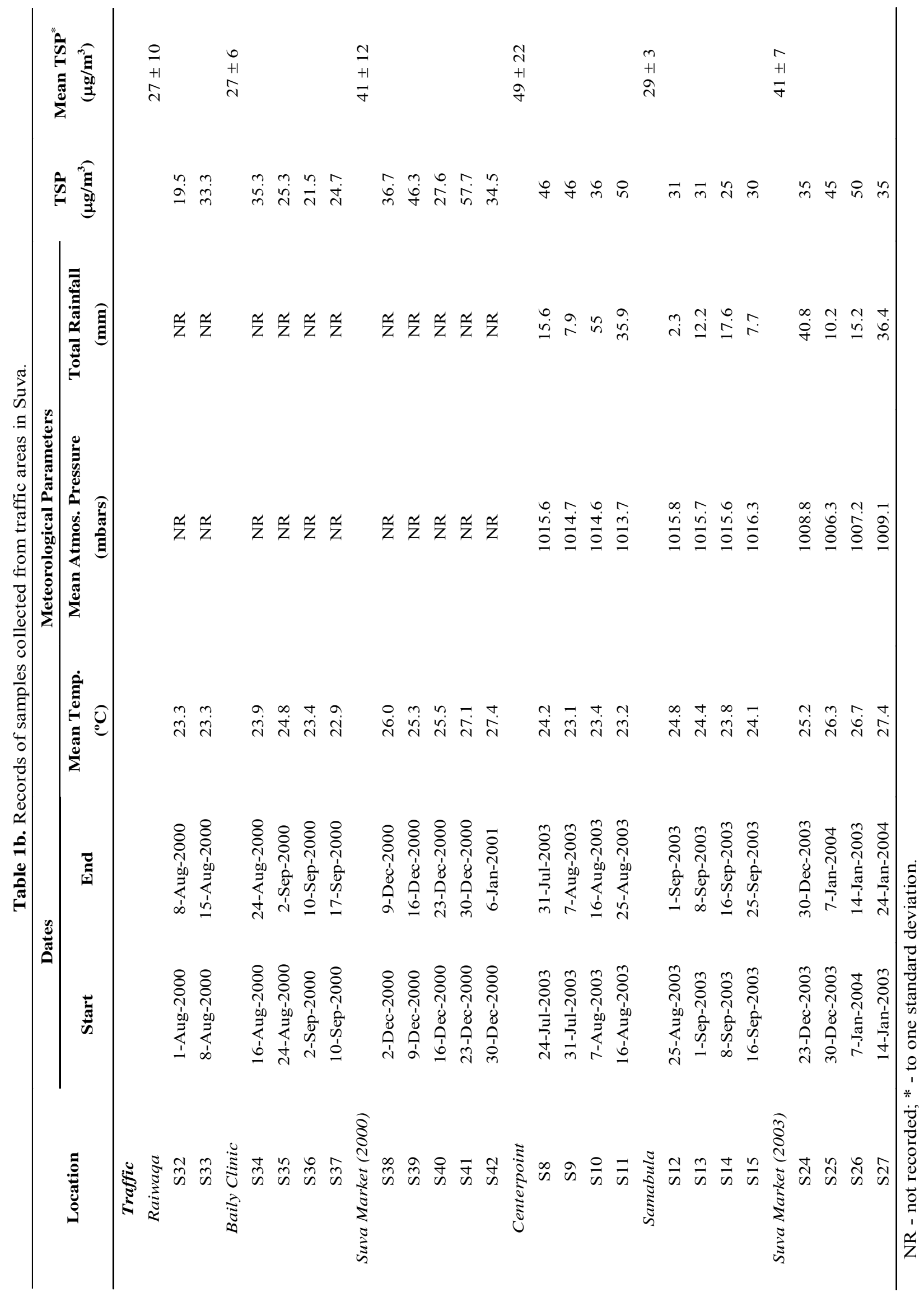




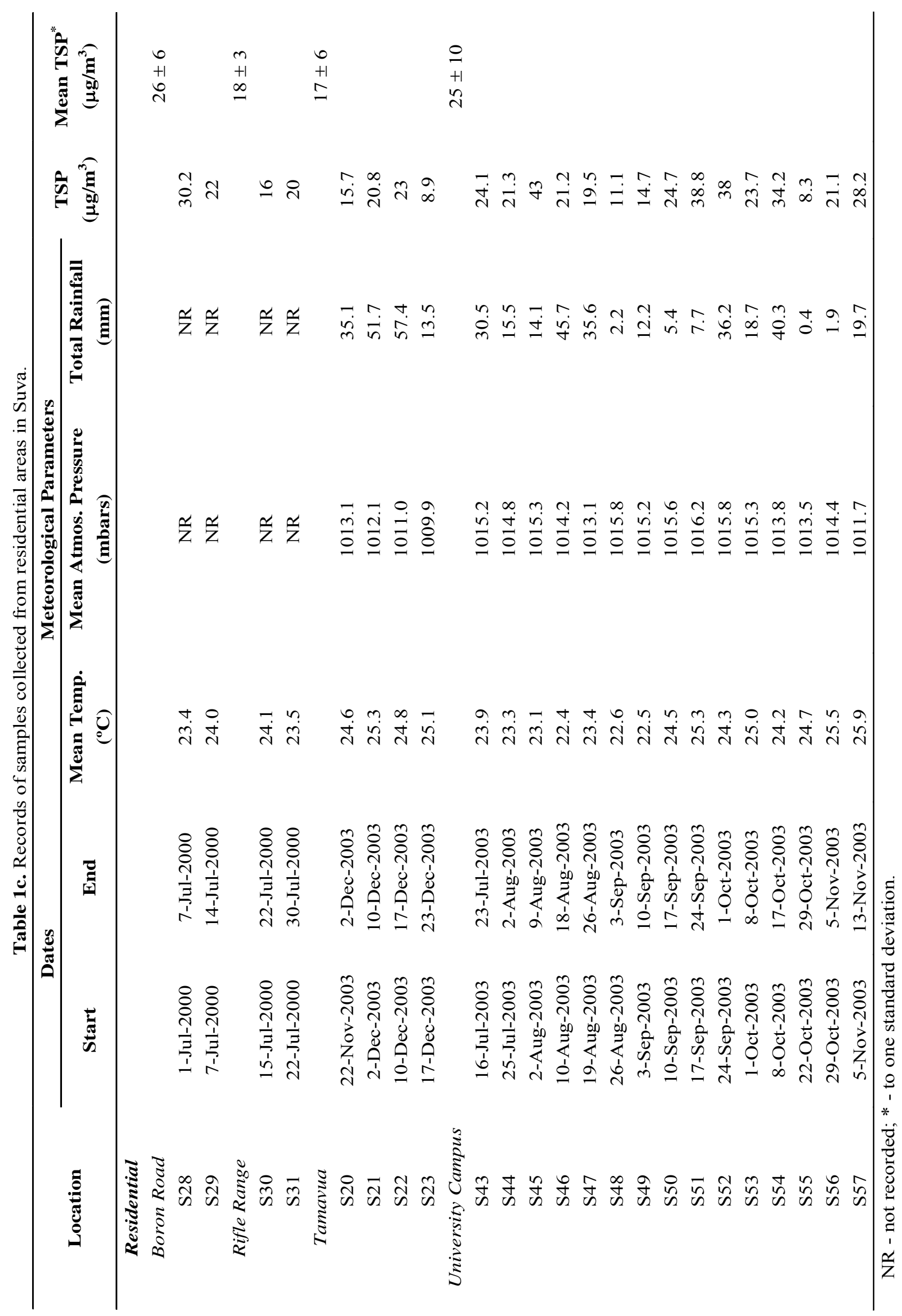


which is the busy Suva City Bus Station). Since it is known that fine particles predominate in automobile exhaust gases, there is an urgent need to characterize the size fractions, particularly in traffic locations, of these aerosols in order to understand better the health implications.

\section{Quality control of NAA result}

Two USGS standards (AGV-1 and RGM-1 (USGS, 2007)), one IAEA standard (SL-1 (IAEA, 2004)) and two standards, namely, BCR-038 and BCR-176 from Commission of the European Communities (CEC, 2007) were used in the present work. AGV-1 is an andesite rock material collected from the eastern side of Guano Valley in Lake County, Oregon (USA). It is aphanitic, finely porphyritic, with a trachytic texture. SL-1 is lake sediment collected at the Sardis Reservoir, Mississippi, USA, from a water depth of $15 \mathrm{~m}$ (Govindraju, 1994; IAEA, 2004). RGM-1 is rhyolite rock material. BCR-038 and BCR-176 are fly ash from pulverized coal and city waste incineration ash, respectively.

AGV-1 and SL-1 are chosen in this work as standards to calculate the elemental concentrations in air filters and in other standards (assuming them as unknowns). The calculated and reference values for the "unknown" standards were compared to assess the accuracy and reliability of the NAA technique. The general agreement between the calculated and reference values was good (errors in concentrations are generally in the range of 5-15\%). Matrix details of samples (rocks, air filters, etc.) do not influence quality of results since the present work involves measurement of high energy gamma rays and the samples are also thin (1-2 $\mathrm{mm})$.

\section{Elemental concentrations in Suva's aerosols}

The range of measured concentrations for 17 elements in air at Suva for residential, traffic and industrial areas is shown in Tables 2(a)-(c). The tables list some environmentally important elements (As, Br, Co, Cr, Fe, Na and $\mathrm{Zn}$ ) and trace elements (Ce, Eu, Hf, $\mathrm{La}, \mathrm{Sc}, \mathrm{Sb}, \mathrm{Sm}, \mathrm{Sr}$, Th and $\mathrm{Yb}$ ). Other important elements, such as $\mathrm{Al}, \mathrm{Ca}, \mathrm{Cd}, \mathrm{Cu}, \mathrm{K}, \mathrm{Mg}$ and $\mathrm{Mn}$, could not be measured in the present work since the radionuclides produced after activation have very small half-lives (a few minutes to hours). Thus, these elements decay to near extinction before they arrive in Suva. Lead $(\mathrm{Pb})$, which is a criteria pollutant specified by the US EPA, could not be measured in the present work because it has a very low thermal neutron cross section (owing to its closed nuclear shell structure). Arsenic being a volatile element can present some problems in measurements. However, the present work was concerned with measurement of solid aerosols. The quality control exercise showed that differences in measured and literature values of As in standards are within 5-7\%. This gives assurance that As volatility is not posing a big problem in the present analysis. 
Table 2a. Range of elemental abundances in TSP $\left(\mathrm{ng} / \mathrm{m}^{3}\right)$ from industrial areas in Suva measured in the present work.

\begin{tabular}{ccccc}
\hline \multirow{2}{*}{ Element } & \multicolumn{4}{c}{ Industrial Areas } \\
\cline { 2 - 5 } & \multicolumn{2}{c}{ Steel Factory } & \multicolumn{2}{c}{ Lami } \\
\cline { 2 - 5 } Range & Average* & $14 \pm 2$ & $0.56-2.03$ & $1.3 \pm 0.7$ \\
$\mathrm{nys}$ & $12-16$ & $11.5 \pm 0.5$ & $2.9-7.6$ & $6.0 \pm 1.7$ \\
$\mathrm{Br}$ & $11.1-11.9$ & $0.81 \pm 0.09$ & $0.14-0.4$ & $0.28 \pm 0.09$ \\
$\mathrm{Ce}$ & $0.72-0.89$ & $6.87 \pm 0.04$ & $0.14-0.87$ & $0.5 \pm 0.3$ \\
$\mathrm{Co}$ & $6.8-6.9$ & $35.3 \pm 2.6$ & $0.2-1.8$ & $1.5 \pm 0.4$ \\
$\mathrm{Cr}$ & $33.5-37.2$ & $\mathrm{ND}$ & $0.009-0.04$ & $0.025 \pm 0.009$ \\
$\mathrm{Eu}$ & $\mathrm{ND}$ & $49562 \pm 1567$ & $379-2249$ & $1403 \pm 867$ \\
$\mathrm{Fe}$ & $47995-51129$ & $\mathrm{ND}$ & $0.02-0.09$ & $0.06 \pm 0.02$ \\
$\mathrm{Hf}$ & $\mathrm{ND}$ & $4.81 \pm 0.1$ & $0.05-0.2$ & $0.13 \pm 0.08$ \\
$\mathrm{La}$ & $4.69-4.93$ & $2749 \pm 1236$ & $707-2366$ & $1427 \pm 494$ \\
$\mathrm{Na}$ & $1875-3623$ & $0.31 \pm 0.03$ & $0.14-0.87$ & $0.6 \pm 0.2$ \\
$\mathrm{Sc}$ & $0.28-0.33$ & $9.2 \pm 0.5$ & $0.4-1$ & $0.6 \pm 0.3$ \\
$\mathrm{Sb}$ & $8.88-9.53$ & $0.130 \pm 0.005$ & $0.025-0.114$ & $0.08 \pm 0.03$ \\
$\mathrm{Sm}$ & $0.12-0.13$ & $\mathrm{ND}$ & $19-30$ & $26 \pm 6$ \\
$\mathrm{Sr}$ & $\mathrm{ND}$ & $\mathrm{ND}$ & 0.02 & 0.02 \\
$\mathrm{Th}$ & $\mathrm{ND}$ & $\mathrm{ND}$ & $0.08-0.18$ & $0.11 \pm 0.05$ \\
$\mathrm{Yb}$ & $\mathrm{ND}$ & $1040 \pm 11$ & $16-179$ & $46 \pm 55$ \\
$\mathrm{Zn}$ & $1032-1048$ & &
\end{tabular}

ND - Not detected; * - to one standard deviation.

Table 2b. Range of elemental abundances in TSP $\left(\mathrm{ng} / \mathrm{m}^{3}\right)$ from traffic areas in Suva measured in the present work.

\begin{tabular}{|c|c|c|c|c|c|c|}
\hline \multirow[b]{2}{*}{ Element } & \multicolumn{5}{|c|}{ Traffic Areas } & \multirow[b]{2}{*}{ Average* } \\
\hline & Raiwaqa & Samabula & Centerpoint & $\begin{array}{c}\text { Suva } \\
\text { Market }\end{array}$ & Baily Clinic & \\
\hline As & $2.8-4.7$ & $1.9-3.2$ & $3.9-6.7$ & $0.9-3$ & $1.5-1.6$ & $3.0 \pm 1.7$ \\
\hline $\mathrm{Br}$ & $2.7-3.2$ & $1.6-2.9$ & $2.1-3.1$ & $4-10$ & $2.1-4.7$ & $3.6 \pm 2.4$ \\
\hline $\mathrm{Ce}$ & $0.12-0.29$ & $0.2-0.32$ & $0.27-0.38$ & $0.11-0.19$ & $0.13-0.27$ & $0.23 \pm 0.09$ \\
\hline $\mathrm{Co}$ & $0.17-0.28$ & $0.28-0.36$ & $0.38-0.42$ & $0.14-0.23$ & $0.26-0.3$ & $0.28 \pm 0.08$ \\
\hline $\mathrm{Cr}$ & $0.8-1.4$ & $1.7-2.6$ & $1.9-3.3$ & $0.5-1$ & $1-1.4$ & $1.7 \pm 0.8$ \\
\hline $\mathrm{Eu}$ & ND & $0.01-0.02$ & $0.009-0.026$ & 0.011 & ND & $0.015 \pm 0.006$ \\
\hline $\mathrm{Fe}$ & $363-672$ & 759-996 & $982-1087$ & $228-436$ & $456-724$ & $670 \pm 279$ \\
\hline $\mathrm{Hf}$ & 0.029 & $0.03-0.05$ & $0.04-0.08$ & $0.016-0.03$ & $0.026-0.034$ & $0.04 \pm 0.02$ \\
\hline $\mathrm{La}$ & $0.10-0.14$ & $0.16-0.19$ & $0.18-0.22$ & $0.041-0.155$ & $0.12-0.22$ & $0.15 \pm 0.05$ \\
\hline $\mathrm{Na}$ & $592-878$ & $971-1747$ & $1046-1667$ & $764-2514$ & $378-946$ & $1150 \pm 608$ \\
\hline $\mathrm{Sc}$ & $0.12-0.22$ & $0.23-0.31$ & $0.31-0.34$ & $0.07-0.14$ & $0.13-0.21$ & $0.21 \pm 0.09$ \\
\hline $\mathrm{Sb}$ & $0.29-0.35$ & $0.62-1.78$ & $0.82-1.27$ & $0.1-0.6$ & $0.6-2.7$ & $0.9 \pm 0.8$ \\
\hline $\mathrm{Sm}$ & $0.02-0.04$ & $0.03-0.05$ & $0.05-0.054$ & $0.013-0.025$ & $0.02-0.04$ & $0.03 \pm 0.01$ \\
\hline $\mathrm{Sr}$ & ND & ND & ND & ND & ND & ND \\
\hline $\mathrm{Th}$ & 0.018 & ND & ND & ND & ND & 0.018 \\
\hline $\mathrm{Yb}$ & ND & ND & ND & ND & ND & ND \\
\hline $\mathrm{Zn}$ & $29-36$ & $47-55$ & $47-54$ & $12-44$ & $37-70$ & $43 \pm 15$ \\
\hline
\end{tabular}

ND-Not detected; *- to one standard deviation. 
Table 2c. Range of elemental abundances in TSP $\left(\mathrm{ng} / \mathrm{m}^{3}\right)$ from residential areas in Suva measured in the present work.

\begin{tabular}{ccccc}
\hline \multirow{2}{*}{ Element } & \multicolumn{3}{c}{ Residential Areas } & \multirow{2}{*}{ Average* } \\
\cline { 2 - 4 } & Boron Road & Rifle Range & Univ. Campus & \\
\hline $\mathrm{As}$ & $1.7-1.9$ & $1.4-4$ & $1.5-3$ & $2.3 \pm 0.9$ \\
$\mathrm{Br}$ & $3.8-4.1$ & $4.5-10.9$ & $3.2-6.8$ & $5.6 \pm 2.9$ \\
$\mathrm{Ce}$ & $0.05-0.09$ & 0.052 & $0.07-0.1$ & $0.07 \pm 0.02$ \\
$\mathrm{Co}$ & $0.14-0.23$ & $0.08-0.09$ & $0.037-0.094$ & $0.11 \pm 0.06$ \\
$\mathrm{Cr}$ & $0.47-0.56$ & $0.52-0.57$ & $0.27-0.44$ & $0.5 \pm 0.1$ \\
$\mathrm{Eu}$ & $\mathrm{ND}$ & $\mathrm{ND}$ & $\mathrm{ND}$ & $\mathrm{ND}$ \\
$\mathrm{Fe}$ & $160-289$ & $166-174$ & $68-154$ & $169 \pm 65$ \\
$\mathrm{Hf}$ & $\mathrm{ND}$ & $0.014-0.015$ & $\mathrm{ND}$ & $0.0145 \pm 0.0005$ \\
$\mathrm{La}$ & $0.035-0.14$ & 0.092 & $0.03-0.15$ & $0.09 \pm 0.05$ \\
$\mathrm{Na}$ & $1038-1380$ & $1088-4650$ & $1560-5498$ & $2536 \pm 1820$ \\
$\mathrm{Sc}$ & $0.053-0.054$ & $0.044-0.048$ & $0.017-0.033$ & $0.04 \pm 0.01$ \\
$\mathrm{Sb}$ & $0.35-0.57$ & 0.946 & $0.21-1.07$ & $0.6 \pm 0.3$ \\
$\mathrm{Sm}$ & $0.01-0.012$ & 0.0076 & $0.0035-0.0086$ & $0.008 \pm 0.003$ \\
$\mathrm{Sr}$ & $\mathrm{ND}$ & $\mathrm{ND}$ & $\mathrm{ND}$ & $\mathrm{ND}$ \\
$\mathrm{Th}$ & $\mathrm{ND}$ & $\mathrm{ND}$ & $\mathrm{ND}$ & $\mathrm{ND}$ \\
$\mathrm{Yb}$ & $\mathrm{ND}$ & $\mathrm{ND}$ & $\mathrm{ND}$ & $\mathrm{ND}$ \\
$\mathrm{Zn}$ & $10-20$ & $17-29$ & $7-28$ & $19 \pm 8$ \\
\hline
\end{tabular}

ND-Not detected; *- to one standard deviation.

Table 3. Sources of atmospheric particulates and their elemental markers (adapted From Le Petit et al., 2002).

\begin{tabular}{cc}
\hline Sources & Markers \\
\hline Crustal Material & $\mathrm{Al}, \mathrm{Mn}, \mathrm{Fe}, \mathrm{Sc}$, and rare earth elements (REE) \\
Sea spray & $\mathrm{Na}, \mathrm{Cl}$ \\
Oil Combustion & $\mathrm{V}, \mathrm{La}, \mathrm{Sm}$ \\
Motor Vehicles & $\mathrm{Br}, \mathrm{Zn}, \mathrm{Sb}, \mathrm{Pb}, \mathrm{Cu}$ \\
Wood Burning & $\mathrm{K}$ \\
Incinerators & $\mathrm{Na}, \mathrm{K}, \mathrm{Cl}, \mathrm{In}, \mathrm{Hg}$ \\
Industrial Urban Areas & $\mathrm{V}, \mathrm{Zn}, \mathrm{Se}, \mathrm{Mo}, \mathrm{Sb}$ \\
Paint Works (automobile) & $\mathrm{Ba}, \mathrm{Ti}$ \\
\hline
\end{tabular}

\section{Sources}

Since industrialization in Fiji is relatively on a small scale, its environment is generally clean. Sources of aerosols in Suva are therefore mainly limited to crustal material, industrial dust, sea spray and vehicular emissions. Table 3 (adapted from Le Petit et al., 2002) lists some elements contributed by these sources to aerosols of Suva.

A first glance at Tables 2(a)-(c) shows that Suva's aerosols are rich in sodium, iron and zinc. Other elements of interest appear to be $\mathrm{As}, \mathrm{Br}, \mathrm{Co}, \mathrm{Cr}$ and $\mathrm{Sb}$, which arise from anthropogenic activities. 
Since the elements measured comprise a small portion of the TSP (mass composition of $\sim 5 \%$ ), it is rather difficult to ascertain all the major sources of TSP in Suva's air. However, an attempt is made to differentiate the levels across the residential, traffic, and industrial categories in order to single out possible anthropogenic sources. This is given next.

\section{$\mathrm{Na}$, Fe and Zn}

Sea spray is the main contributor for sodium in aerosols and its distribution is influenced by the SE winds and the geography of the Suva peninsula: The USP Campus (Site 11, Fig. 1) and the Rifle Range (1) are very close to the sea and therefore have very high Na levels. Baily Clinic (6) and Suva Market (7), which are on the western side of the peninsula, are shielded from SE winds by hills and tall buildings, have low sodium levels. Further, sea sprays consist of coarse particles and are expected to have small residence times in the atmosphere. For this reason they are also not expected to travel long distances.

Average levels of iron observed in aerosols were $1403 \pm 867 \mathrm{ng} / \mathrm{m}^{3}$ for industrial, $670 \pm 279$ $\mathrm{ng} / \mathrm{m}^{3}$ for traffic and $169 \pm 65 \mathrm{ng} / \mathrm{m}^{3}$ for residential areas. Elevated levels in industrial and traffic areas compared to residential areas point to possible anthropogenic input. It is believed that much of the iron in Suva's aerosols is contributed by dust from soil, road and construction sites.

Zinc was found to be elevated in TSP from the traffic and industrial areas $\left(40-50 \mathrm{ng} / \mathrm{m}^{3}\right.$, which is about twice that observed in residential areas). The highest zinc level recorded was at Lami $\left(179 \pm 2 \mathrm{ng} / \mathrm{m}^{3}\right)$. Zinc is used in the manufacture of tyres (zinc oxide is a vulcanization activator), and brake pads. Its composition in tyres can range 8,000-17,000 ppm, depending upon the level of zinc oxide added (David and Williams, 1975; Kennedy and Gadd, 2003) and 96-34,600 ppm in brake pads (Kennedy and Gadd, 2003). In Suva, zinc is believed to arise mainly from the wear-off of automobile tyres and brake pads, as well as automobile exhaust emissions.

The EPA guideline values for these elements are not available for comparison.

\section{As, $\mathrm{Br}, \mathrm{Co}, \mathrm{Cr}$ and $\mathrm{Sb}$}

Arsenic levels in Suva's aerosols are generally in the range of $1-3 \mathrm{ng} / \mathrm{m}^{3}$, with the highest concentration of $6.70 \pm 0.07 \mathrm{ng} / \mathrm{m}^{3}$ observed at Centerpoint (a busy traffic junction). This is still lower than the chronic inhalation reference level of $30 \mathrm{ng} / \mathrm{m}^{3}$ established by the California Environmental Protection Agency (CalEPA, 1997). Kennedy and Gadd (2003) investigated the elemental composition of tyres, brake pads and road butimen. Their median values of As in the road butimen and brake-pad dust samples were 1.5 and 3.5 ppm respectively.

The main source of bromine in aerosols is motor vehicles (Ganley and Springer, 1974) in the form of lead halides (both $\mathrm{Cl}$ and $\mathrm{Br}$ included). Marine aerosols also contain some $\mathrm{Br}$, but their contribution to total $\mathrm{Br}$ does not exceed 5\% even at seaside locations (Jernigan et al., 1971; 
Martens et al., 1973). Bromine levels in Suva's air at residential areas is found to be in the range $2-4 \mathrm{ng} / \mathrm{m}^{3}$, while an average value about $7 \mathrm{ng} / \mathrm{m}^{3}$ was found in industrial and traffic areas.

Chromium levels in air at industrial and traffic areas was found to be about $1.6 \mathrm{ng} / \mathrm{m}^{3}$, which is about thrice the value observed for residential areas. EPA (2003) estimates that continuously breathing air containing $0.8 \mathrm{ng} / \mathrm{m}^{3}$ of $\mathrm{Cr}$ would result in less than a one-in-a-hundred thousand increased risk of developing cancer during one's lifetime. $\mathrm{Cr}$ is a major component in the manufacture of brake pads. Kennedy and Gadd (2003) reported a median value of 329 ppm in brake-pad dust samples.

Suva's residential areas had an average Co level of $0.11 \pm 0.06 \mathrm{ng} / \mathrm{m}^{3}$, while concentrations in traffic and industrial areas are higher by factors of 3 and 5 respectively. EPA (2003) considers a threshold value of $5 \mathrm{ng} / \mathrm{m}^{3}$ for cobalt for non-cancer exposure. Kennedy and Gadd (2003) reported a median concentration of $28 \mathrm{ppm}$ in road butimen, as well as in brake-pad dust samples. In the traffic areas, these are believed to be the major sources of Co.

Elevated levels of antimony recorded in traffic areas $\left(1-3 \mathrm{ng} / \mathrm{m}^{3}\right)$ compared to the residential areas $\left(0.2-1 \mathrm{ng} / \mathrm{m}^{3}\right)$ indicate that this element could be used as a possible tracer for air pollution by automobile emissions. The UK Environmental Agency (1998) reported that antimony pentasulphide is used as a colorant in tyre production. Sutherland and Tolosa (2000) showed that the major source of antimony in road side dust could be the wear of asbestos-free brake linings. Kennedy and Gadd (2003) reported a value of 29,500 ppm for Sb in one of the brake pads they examined. They attributed antimony sulphide, which is used as a lubricant in the pad, as the major cause.

\section{Rare earth and other trace elements}

As can be seen from Table 2, observed concentrations of rare earth $(\mathrm{Ce}, \mathrm{Eu}, \mathrm{La}$ and $\mathrm{Sm})$ and other trace elements (Hf, Sc and Th) in air at Suva are below $1 \mathrm{ng} / \mathrm{m}^{3}$. The main source of these elements is the Earth's crust. Strontium was detected only in the aerosols from Lami which contains a cement factory close to the sampling site.

\section{Evaluation of anthropogenic input}

To confirm any anthropogenic input of elements into air, it is necessary to calculate the enrichment factors (EF) for each element. The EF is defined as the ratio of the concentration of an element of interest $\left(\mathrm{X}_{\mathrm{i}}\right)$ in the sample to that of a reference element $\left(\mathrm{C}_{\mathrm{i}}\right)$ in the sample; i.e., $\left(\mathrm{X}_{\mathrm{i}} / \mathrm{C}_{\mathrm{i}}\right)_{\text {sample, }}$ divided by the same ratio in a reference material, $\left(\mathrm{X}_{\mathrm{i}} / \mathrm{C}_{\mathrm{i}}\right)_{\text {ref. }}$ The Earth's crust is generally chosen as reference material (Bilos et al., 2001; Le Petit et al., 2002).

In view of natural variation of the Earth's crustal composition, EFs for elements show some degree of uncertainty, but the EFs should be an order of magnitude higher than unity (Bilos., 2001) or even greater than $10^{2}$ (Le Petit et al., 2001) to suggest anthropogenic origin. Using the 
mean elemental abundances of Earth's crust given by Taylor and McLennan (1985), the EFs derived for some elements in Suva's aerosols are shown in Table 4. Scandium was chosen as the reference element because of its low volatility and lack of anthropogenic sources (Le Petit et al., 2002).

Table 4. Calculated enrichment factors (EF) for the elements in air at Suva derived relative to Earth's crust.

\begin{tabular}{cccc}
\hline Element & $\begin{array}{c}\text { Mean conc. in air } \\
\left(\mathbf{n g} / \mathbf{m}^{\mathbf{3}}\right)\end{array}$ & $\begin{array}{c}\text { Relative abundance in } \\
\text { Earth's crust }\end{array}$ & $\begin{array}{c}\text { Enrichment } \\
\text { factor (EF) }\end{array}$ \\
\hline $\mathrm{Sb}$ & 0.8 & 0.2 & 632 \\
$\mathrm{As}$ & 2.6 & 1 & 411 \\
$\mathrm{Zn}$ & 41 & 80 & 81 \\
$\mathrm{Na}$ & 1655 & $3.1(\%)$ & 8 \\
$\mathrm{Sr}$ & 26 & 260 & 16 \\
$\mathrm{Hf}$ & 0.04 & 3 & 2 \\
$\mathrm{Co}$ & 0.3 & 29 & 2 \\
$\mathrm{Cr}$ & 1.2 & 185 & 1 \\
$\mathrm{Fe}$ & 575 & $9.1(\%)$ & 1 \\
$\mathrm{Sc}$ & 0.19 & 30 & 1 \\
& & & \\
$\mathrm{Yb}$ & Rare Earth Elements & & 9 \\
$\mathrm{Eu}$ & 0.13 & 2.2 & 3 \\
$\mathrm{Sm}$ & 0.02 & 1.1 & 1.4 \\
$\mathrm{La}$ & 0.03 & 3.5 & 1.3 \\
$\mathrm{Ce}$ & 0.13 & 16 & 1 \\
$\mathrm{Th}$ & 0.2 & 33 & 1 \\
\hline
\end{tabular}

* Source: Taylor and McLennan (1985); all units in ppm, except where noted otherwise.

The EF's calculated in Table 4 have a bias towards traffic areas (more traffic areas were studied). Suva's aerosols are generally enriched with $\mathrm{Sb}, \mathrm{As}, \mathrm{Na}$, and $\mathrm{Zn}$. Sodium enrichment is expected for Suva, due to its geographical location. The high EFs suggest that there are sources apart from soil dust that contribute towards their loadings. Arsenic and antimony are known to be present in diesel exhausts (Stechmann, 1993; CalEPA, 2004).

$\mathrm{EFs}$ for $\mathrm{Cr}$ and $\mathrm{Fe}$ are close to unity, suggesting soil dust or road dust as the potential sources. However, these elements have been measured in elevated levels near traffic and industrial areas, which often have poorly maintained road infrastructure. Thus, even though their sources are natural, their re-suspension into the air is caused mainly by vehicle usage. In this way, motor vehicles and hence anthropogenic activity is indirectly contributing towards air pollution in Suva.

EFs for rare earth elements in air, as expected, were found to be close to unity, since these elements are mostly derived from soil dust. EFs for elements $\mathrm{Yb}$ and Eu were higher (similarly for Sr), mainly due to the site at Lami which is close to a cement factory. 


\section{CONCLUSIONS}

This work supplies the hitherto not available data on atmospheric aerosols and its elemental concentrations in air in the South Pacific Islands, which is perhaps necessary for global understanding of aerosols. It also provides a baseline work for the parties interested in the Fiji Management Act of 2005 to refer to when the need arises. The airborne particulate matter in Suva is dominated by marine aerosols. Though most locations in these islands are pristine, TSP levels recorded in Suva were in the wide range of $9-91 \mu \mathrm{g} / \mathrm{m}^{3}$, giving an annual average of $40 \pm$ $13 \mu \mathrm{g} / \mathrm{m}^{3}$. In some industrial locations, TSP values are occasionally close to the upper WHO limit for pollution. Calculated enrichment factors for some elements (As, $\mathrm{Sb}$ and $\mathrm{Zn}$ ) measured in this work show that anthropogenic inputs into the air occur through automobile emissions.

The Land Transport Authority of Fiji has recently started enforcing maximum emission levels for vehicles running on diesel fuel. This act perhaps would help bring down the emission levels from the automobiles running on Fiji roads. Also, certain relaxations on import duty have allowed taxi drivers in Fiji to switch from their diesel operated cars to vehicles running on liquid petroleum gases (LPG). It was believed that this transition would: a) reduce exhaust emissions, and contribute towards a 'cleaner' air; b) cheaper running of taxis. It is envisaged that emissions from traffic would be drastically lowered over the next few years due to these initiatives. As the field work in this study was conducted prior to the LPG cars being introduced onto Fiji roads, this work serves as a very good reference point for any future studies for comparison. Moreover, with the establishment of the National Environmental Council, it is believed that emissions and wastes from industrial activities would also be reduced.

\section{ACKNOWLEDGEMENTS}

This work is supported by a generous grant from the University of the South Pacific, Suva, Fiji. The authors would like to thank the Fiji Police Force which allowed its premises in various parts of the Suva City to be used for air sampling, as well as for providing security for the equipment in these locations. The authors also would like to thank the Physics Technical Staff of the university for their help in transporting samplers and maintaining the equipment used in this work. Thanks are also due to Professor Kanayathu Koshy, Director of Pacific Centre for Sustainable Development at USP, for his valuable comments concerning the policies in place for environmental sustainability in Fiji. Finally, the authors thank ANSTO, Sydney, for irradiating our samples and sending them back to Suva for measurements. 


\section{REFERENCES}

Aneja, V.P., Agarwal, A., Rolle, P.A., Phillips, S.B., Tong, Q., Watkins, N. and Yablonski, R. (2001). Measurements and Analysis of Criteria Pollutants in New Delhi, India. Environ. Int. 27: $35-42$.

Bilos, C., Colombo, J.C., Skorupka, C.N. and Rodriguez, Presa M.J. (2001). Sources, Distribution and Variability of Airborne Trace Metals in La Plata City area, Argentina. Environ. Int. 111: 149-158.

Boubel, R.W., Fox, D.L., Turner, D.B. and Stern. A.C. (1994). Fundamentals of Air Pollution. Academic Press Inc., San Diego.

Bridgeman, H. (1990). Global Air Pollution: Problems for the 1990's. Belhaven Press, London.

CalEPA. California Environmental Protection Agency. (1997). Technical Support Document for the Determination of Noncancer Chronic Reference Exposure Levels. Draft for Public Comment. Office of Environmental Health Hazard Assessment, Berkeley, CA.

CEC. (2007). Commission of the European Communities, Catalogue of Reference Materials. http://www.ec.europa.eu, June 2007.

David, D.J. and Williams, C.H. (1975). Heavy Metal Contents of Soils and Plants Adjacent to the Hume Highway near Marulan, New South Wales. Aust. J. Exp. Agric. Anim. Husb. 15: 414-417.

Environment Agency. (1998). Tyres and the Environment. United Kingdom Environment Agency.

EPA. (1999). Chemical Species Analysis of Filter-collected Suspended Particulate Matter (SPM). In: "Compendium of Methods for the Determination of Inorganic Compounds in Ambient Air”, Chapter IO-3, EPA/625/R-96/010a.

EPA. (2003). Air Toxics Website. http://www.epa.gov/ttn/atw/hlthef/.

Ganley, J.T. and Springer, G.S. (1974). Physical and Chemical Characteristics of Particulates in Spark Ignition Exhaust. Environ. Sci. Technol. 8: 340-347.

Govindraju, K. (1994). Compilation of Working Values and Descriptions for 383 Geostandards. Geostandards Newsletter. 18: 15-16.

Hope, L.A.E. and Gooding, D.A. (2001). Particulate Air Quality at Whyalla, South Australia. Environmental Protection Authority, Department of Environmental Heritage, GPO Box 2607, Adelaide, SA 5001.

IAEA. (2004). Analytical Quality Control Services, International Atomic Energy Agency, Reference Materials Catalogue, Vienna, 2004-2005.

Jernigan, E.L., Ray, B.J. and Duce, R.A. (1971). Lead and Bromine in Atmospheric Particulate Matter on Oahu, Hawaii. Atmos. Environ. 5: 881-886. 
Kennedy, P. and Gadd, J. (2003). Preliminary Examination of Trace Elements in Tyres, Brake Pads and Road Butimen in New Zealand. Prepared for Ministry of Transport, New Zealand by Kingett Mitchell Limited, November, 2000, revised October, 2003.

Landsberger, S. (1994). Delayed Instrumental Neutron Activation Analysis. In Chemical Analysis by Nuclear Methods. Alfassi, Z.B. (Ed), John Wiley, Chichester.

Le Petit, G., Deschamps, J.P. and Nouchpramools, S. (2002). Trace Elements in Total Atmospheric Suspended Particles in a Suburban Area of Paris: A Study Carried Out by INAA. In: Environmental Changes and Radioactive Tracers, IRD'Editions, Paris, pp 299-321.

Martens, C.S., Wesolowski, J.J., Kaifer, R. and John, W. (1973). Pb and Br Particle Size Distributions in the San Francisco Bay Area. Atmos. Environ. 7: 905-914.

Prospero, J.M., Savoie, D.L. and Arimoto, R. (2003). Long-term Record of NSS-Sulphate and Nitrate in Aerosols on Midway Island, 1981-2000: Evidence of Increased (now decreased?) Anthropogenic Emissions from Asia. J. Geophys. Res. 108: (D1), 4019, doi:10.1029/2001JD001524.

Rao, M.N. and Rao, H.V.N. (1989). Air Pollution. Tata McGraw-Hill Publishing Company, New Delhi.

Salaam, A., Bauer, H., Kassin, K., Ullah, S.M. and Puxbaum, H. (2003). Aerosol Chemical Characteristics of a Mega-city in Southeast Asia (Dhaka-Bangladesh). Atmos. Environ. 37: 2517-2528.

Shaw, G.E. (1980). Optical, Chemical and Physical Properties of Aerosols over Antarctic Sheet. Atmos. Environ. 14(8): 911-921.

Stechmann, H. (1993). Charakterisierung kraftfahrzeugspezifischer partikelförmiger Emissionen und Quantifizierung ihrer Beiträge zu Aerosolen und Gewässerverunreinigungen (in German). Dannecker, Hamburg.

Sutherland, R.A. and Tolosa, C.A. (2000). Multi-element Analysis of Road Deposited Sediment in an Urban Drainage Basin, Honolulu, Hawaii. Environ. Pollut. 111: 483-495.

Taylor, S.R. and McLennan, S.M. (1985). The Continental Crust: Its Composition and Evolution. Blackwell Scientific Publishers, Oxford.

Uematsu, M., Duce, R.A. and Prospero, J.M. (1994). Atmospheric Beryllium-7 Concentrations over the Pacific. Geophys. Res. Lett. 21(7): 561-564.

USGS. (2007). United States Geological Survey Reference Chemical Materials and Certificates. http://minerals.cr.usgs.gov/geo_chem_stand/andesite1.html

Received for review, May 1, 2007 Accepted, July 12, 2007 